\title{
Prevalensi Depresi pada Pensiunan Pegawai Negeri Sipil yang Mengambil Dana Pensiun di Bank BTPN Cabang M. Yamin Padang
}

Finna Dwi Putri ${ }^{1}$, Amel Yanis $^{2}$, Elmatris ${ }^{3}$

\begin{abstract}
Abstrak
Pensiun seringkali dianggap sebagai kenyataan yang tidak menyenangkan sehingga menjelang masanya tiba, sebagian orang sudah merasa cemas karena tidak tahu kehidupan seperti apa yang akan dihadapi kelak. Individu yang memiliki kondisi mental yang tidak stabil sering menjadi akar penyebab terjadinya gangguan mental semasa pensiun yaitu depresi. Depresi merupakan salah satu gangguan mood yang ditandai oleh hilangnya perasaan kendali seseorang. Tujuan penelitian ini adalah untuk mengetahui prevalensi depresi pada pensiunan Pegawai Negeri Sipil yang mengambil dana pensiun di Bank BTPN Cabang M. Yamin Padang. Penelitian ini bersifat deskriptif dan subjek dipilih secara consecutive sampling dengan jumlah 277 orang. Instrumen yang digunakan adalah kuesioner Beck Depression Inventory dan hasil yang didapatkan disajikan dalam bentuk tabel distribusi frekuensi. Hasil penelitian ini menunjukkan bahwa prevalensi depresi pada pensiunan Pegawai Negeri Sipil yang mengambil dana pensiun di Bank BTPN Cabang M. Yamin Padang sebesar 27,8\%. Usia terbanyak berada pada kategori usia $\geq 60$ tahun, gejala depresi terbanyak terjadi pada pensiunan laki-laki, prevalensi depresi terbanyak pada pensiunan Pegawai Negeri Sipil golongan Illa. Prevalensi terbanyak adalah pensiunan yang menjalani lama pensiun $\leq 10$ tahun.
\end{abstract}

Kata kunci: depresi, pensiun, pegawai negeri sipil

\begin{abstract}
Retirement is often regarded as unpleasant fact that before it's time comes, most people are worried because they do not know what kind of life to be faced later. Individuals who have an unstable mental condition is often the root causes of mental disorders during retirement i.e depression. Depression is a mood disorder characterized by loss of control of one's feelings. The objective of this study was to determine the prevalence of depression in retired civil servants who take the retirement funds in BTPN Bank branch M. Yamin Padang. This was a descriptive study and subjects were chosen by consecutive sampling with total sampling 277 persons. Instrument of this study was questionnaire of Beck Depression Inventory and the results obtained are presented in the form of a frequency distribution table. The result of this study indicated that the prevalence of depression in retired civil servants who take retirement funds in BTPN Bank branch M. Yamin Padang was 27.8\%. Most of them are at the age category of $\geq 60$ years, most of symptoms of depression is in men, the largest prevalence of depression in retired civil servant class IIla. The most of them are the retirees who have retired for $\leq 10$ years.
\end{abstract}

Keywords: depression, retirement, civil servants

Affiliasi penulis :1. Pendidikan Dokter FK UNAND (Fakultas Kedokteran Universitas Andalas Padang), 2. Bagian IImu Psikiatri FK UNAND/RS Dr. M. Djamil Padang, 3. Bagian Kimia FK UNAND. Korespondensi : Finna Dwi Putri, E-mail: fynnaputtry@yahoo.com, Telp: +6285265484999

\section{PENDAHULUAN}

Bekerja merupakan suatu kegiatan yang dilakukan individu untuk mencapai suatu kesejahteraan dan kelangsungan hidup. Dengan 
bekerja, disamping individu bisa mendapatkan penghasilan dan fasilitas, bekerja juga merupakan suatu status sosial untuk memperoleh kepuasan serta kebanggaan tersendiri. ${ }^{1}$

Pada saat individu memperoleh suatu prestasi dari pekerjaannya, individu akan mengaktualisasikan secara optimal kemampuan dan kreativitas yang dimiliki sehingga memperoleh suatu penghargaan yang baik dalam tempatnya bekerja. Akan tetapi, ada saatnya seseorang yang bekerja akan pensiun dari pekerjaannya karena setiap perusahaan atau organisasi mempekerjakan karyawan sampai batas usia tertentu. $^{2}$

Ketakutan dalam menghadapi masa pensiun membuat banyak orang mengalami masalah serius baik dari sisi kejiwaan maupun fisik. ${ }^{3}$ Pada individu dengan kondisi kejiwaan yang stabil, konsep diri positif, rasa percaya diri kuat serta didukung oleh keuangan yang cukup, maka individu tersebut akan lebih dapat menyesuaikan diri dengan kondisi pensiun tersebut. Namun individu yang mengalami problem saat pensiun biasanya justru mereka yang memiliki kondisi mental yang tidak stabil, konsep diri yang negatif dan rasa kurang percaya diri terutama berkaitan dengan kompetensi diri dan keuangan. ${ }^{2}$

Pegawai Negeri Sipil (PNS) merupakan pihak yang paling takut menghadapi masa pensiun. Berdasarkan data dari Badan Kepegawaian daerah, Batas Usia Pensiun (BUP) bagi PNS adalah 56 tahun. ${ }^{4}$ Pegawai Negeri Sipil yang memasuki masa pensiun, baik sukarela maupun terpaksa, menyebabkan hilangnya identitas peran. Tuntutan hidup yang terus mendesak dan dirinya adalah satu-satunya penopang hidup keluarga, menyebabkan risiko terjadinya depresi semakin besar. $^{5}$

Menurut seorang ilmuwan terkemuka yaitu Aaron T.Beck, depresi adalah gangguan mood, konsep diri yang negatif yang berlanjut pada perasaan rendah diri, gangguan terhadap fungsi fisiologis, dan kondisi emosional berkepanjangan yang mewarnai seluruh proses mental (berpikir, berperasaan dan berperilaku) seseorang. ${ }^{6}$

Berdasarkan data World Health Organization
(WHO), sekitar 121 juta orang di dunia menderita depresi yaitu dengan prevalensi selama kehidupan pada wanita $10-25 \%$, pada laki-laki $5-12 \%$, dan angka kejadian bunuh diri yang disebabkan oleh depresi ini adalah 850.000 tiap tahun. Menurut Disability Adjusted Life Year (DALY), diperkirakan pada tahun 2020 depresi akan menduduki peringkat ke dua dunia. ${ }^{7}$ Berdasarkan data riset kesehatan dasar tahun 2007 yang diadakan Departemen Kesehatan RI, gangguan depresi dialami sekitar $11,6 \%$ dari populasi Indonesia (24.708.000 orang) yang usianya di atas 15 tahun. ${ }^{8}$

Sebagaimana yang dikutip Eliana, penelitian yang dilakukan oleh Holmes dan Rahe bahkan, mengungkapkan bahwa masa pensiun menempati rangking 10 besar untuk posisi depresi. ${ }^{9}$

Beberapa studi secara konsisten melaporkan antara 30-33\% pensiunan menyatakan berbagai perasaan negatif menjadi pensiunan. ${ }^{10}$

Penelitian terhadap lansia dengan menggunakan Geriatric Scoring System (GSS), didapatkan 14\% lansia mengalami depresi akibat pensiun. ${ }^{11}$ Penelitian ini bertujuan untuk mengetahui prevalensi depresi pada pensiunan PNS yang mengambil dana pensiun di Bank BTPN Cabang M. Yamin Padang.

\section{METODE}

Penelitian ini dilaksanakan di Bank BTPN Cabang M. Yamin Padang selama bulan FebruariMaret 2013. Penelitian ini bersifat deskriptif dan subjek dipilih secara consecutive sampling dengan jumlah 277 orang. Subjek adalah pensiunan PNS yang mengambil dana pensiun di Bank BTPN Cabang M. Yamin Padang yang memenuhi kriteria inklusi dan tidak memiliki kriteria eksklusi. Seluruh data primer dan sekunder yang didapatkan dari bagian administrasi Bank BTPN Cabang M. Yamin Padang diambil datanya, kemudian diolah secara manual berdasarkan kelompok-kelompok variabel yang diteliti yaitu depresi, usia, jenis kelamin, lama pensiun, dan golongan/pangkat PNS. Instrumen yang digunakan adalah kuesioner Beck Depression Inventory dan analisis data meliputi analisis univariat. 
HASIL

Tabel 1. Distribusi frekuensi subjek penelitian berdasarkan karakteristik

\begin{tabular}{|c|c|c|c|}
\hline \multicolumn{2}{|c|}{ KARAKTERISTIK } & Frekuensi & $\%$ \\
\hline \multirow{3}{*}{ USIA } & $40-59$ & 93 & 33,6 \\
\hline & $\geq 60$ & 184 & 66,4 \\
\hline & Total & 277 & 100 \\
\hline \multirow{3}{*}{ JENIS KELAMIN } & Laki-laki & 206 & 74,4 \\
\hline & Perempuan & 71 & 25,6 \\
\hline & Total & 277 & 100 \\
\hline \multirow{13}{*}{$\begin{array}{c}\text { GOLONGAN/ } \\
\text { PANGKAT }\end{array}$} & Ila & 9 & 3,24 \\
\hline & Ilb & 7 & 2,52 \\
\hline & Ilc & 3 & 1,1 \\
\hline & Ild & 14 & 5,05 \\
\hline & Illa & 32 & 11,5 \\
\hline & IIlb & 38 & 13,7 \\
\hline & IIlc & 43 & 15,5 \\
\hline & IIId & 60 & 21,7 \\
\hline & Iva & 28 & 10,1 \\
\hline & $\mathrm{IVb}$ & 28 & 10,1 \\
\hline & IVc & 13 & 4,7 \\
\hline & IVd & 2 & 0,72 \\
\hline & Total & 277 & 100 \\
\hline \multirow{3}{*}{ LAMA PENSIUN } & $\leq 10$ tahun & 187 & 67,5 \\
\hline & $>10$ tahun & 90 & 32,5 \\
\hline & Total & 277 & 100 \\
\hline \multirow{5}{*}{$\begin{array}{c}\text { TINGKATAN } \\
\text { DEPRESI }\end{array}$} & Normal & 200 & 72,2 \\
\hline & Ringan & 66 & 23,8 \\
\hline & Sedang & 11 & 4 \\
\hline & Berat & - & - \\
\hline & Total & 277 & 100 \\
\hline
\end{tabular}

Berdasarkan Tabel 1 dapat dilihat bahwa angka distribusi subjek dilihat berdasarkan usia, jenis kelamin, golongan/pangkat, lama pensiun, dan tingkatan depresi. Dari karakteristik tingkatan depresi didapatkan bahwa dari 277 orang responden terdapat 77 orang yang menunjukkan gejala depresi.

Tabel 2. Prevalensi depresi berdasarkan usia

\begin{tabular}{ccc}
\hline Usia (tahun) & Frekuensi & $\%$ \\
\hline $40-59$ & 17 & 22,1 \\
\hline$\geq 60$ & 60 & 77,9 \\
\hline Jumlah & 77 & 100 \\
\hline
\end{tabular}

Tabel 2 memperlihatkan bahwa prevalensi depresi berdasarkan usia yang terbanyak berada pada kategori usia $\geq 60$ yaitu $77,9 \%$. Individu dengan konsep diri positif, rasa percaya diri kuat serta didukung oleh keuangan yang cukup, maka individu tersebut akan lebih dapat menyesuaikan diri dengan kondisi pensiun tersebut. Namun individu yang mengalami problem saat pensiun biasanya justru mereka yang memiliki konsep diri yang negatif dan rasa kurang percaya diri terutama berkaitan dengan kompetensi diri dan keuangan. ${ }^{2}$

Tabel 3. Prevalensi depresi berdasarkan jenis kelamin

\begin{tabular}{ccc}
\hline Jenis Kelamin & Frekuensi & $\%$ \\
\hline Laki-laki & 71 & 92,2 \\
\hline Perempuan & 6 & 7,8 \\
\hline Jumlah & 77 & 100
\end{tabular}

Pada Tabel 3 dapat dilihat bahwa prevalensi depresi terbanyak terjadi pada laki-laki yaitu $92,2 \%$ sedangkan pada perempuan hanya $7,8 \%$. Jenis kelamin juga merupakan salah satu faktor dalam mencetuskan terjadinya depresi pada pensiunan. Menurut literatur, depresi lebih sering terjadi pada wanita sekitar $20 \%$ dan $12 \%$ pada laki-laki. ${ }^{12}$ Perbedaan hasil ini disebabkan karena berdasarkan data statistik dari Badan Kepegawaian Negara, mayoritas PNS adalah berjenis kelamin laki-laki yaitu $62,3 \%$. Menurut literatur, risiko terjadinya depresi akan semakin besar apabila PNS yang memasuki masa pensiun merupakan seorang kepala keluarga yang merupakan satu-satunya penopang hidup keluarga dan ditambah tuntutan hidup yang terus mendesak. ${ }^{5}$

Berdasarkan Tabel 4 dapat dilihat bahwa prevalensi depresi terbanyak pada pensiunan PNS golongan IIla yaitu 23,4\%. Menurut Badan Kepegawaian Negara, golongan IIla merupakan pegawai negeri dengan tingkat pendidikan S1/sederajat. Berdasarkan golongan/pangkat ini juga dapat ditentukan gaji yang akan diterima oleh PNS. 
Tabel 4. Prevalensi depresi berdasarkan golongan/pangkat

\begin{tabular}{ccc}
\hline Golongan/Pangkat & Frekuensi & $\%$ \\
\hline Ila & 9 & 11,7 \\
\hline Ilb & 0 & 0 \\
\hline Ilc & 0 & 0 \\
\hline Ild & 5 & 6,5 \\
\hline IIla & 18 & 23,4 \\
\hline IIlb & 8 & 10,4 \\
\hline IIIc & 12 & 15,6 \\
\hline IIld & 13 & 16,9 \\
\hline IVa & 3 & 3,9 \\
\hline IVb & 6 & 7,8 \\
\hline IVc & 3 & 3,9 \\
\hline IVd & 0 & 0 \\
\hline Jumlah & 77 & 100 \\
\hline & &
\end{tabular}

Menurut Peraturan Pemerintah Republik Indonesia Nomor 15 tahun 2013, gaji pokok yang akan diterima oleh PNS golongan IIla adalah Rp. 2.046.100 perbulan. Pada saat PNS pensiun, mereka akan menerima dana pensiun sebesar $75 \%$ dari gaji pokok tersebut. Hal ini akan memberatkan keluarga yang keuangannya benar-benar tergantung dari pekerjaan ayah sebagai kepala keluarga. Masalah ini akan lebih sulit jika saat pensiun mereka masih memiliki tanggungan anak sekolah. ${ }^{9}$

Tabel 5. Prevalensi depresi berdasarkan lama pensiun

\begin{tabular}{ccc}
\hline Lama Pensiun & Frekuensi & $\%$ \\
\hline$\leq 10$ tahun & 39 & 50,6 \\
\hline$>10$ tahun & 38 & 49,4 \\
\hline Jumlah & 77 & 100 \\
\hline
\end{tabular}

Berdasarkan Tabel 5 di atas, dapat dilihat bahwa prevalensi depresi lebih banyak ditunjukkan pada pensiunan PNS yang menjalani lama pensiun $\leq 10$ tahun yaitu $50,6 \%$. Hal ini sesuai dengan penelitian yang telah dilakukan oleh Agustianto yang menunjukkan bahwa dari 46 responden yang lama pensiunnya $\leq 10$ tahun, terlihat bahwa 25 responden $(54,3 \%)$ memiliki penyesuaian diri yang negatif yang dapat menimbulkan depresi. Menurut literatur, lama pensiun merupakan suatu rentang waktu seseorang menjalani masa pensiunnya. Gangguan psikologis salah satunya depresi banyak dialami oleh mereka yang baru saja menjalani masa pensiun sehingga lama pensiun dapat mempengaruhi penyesuaian diri ketika pensiun. Hal ini berarti bahwa semakin lama seseorang menjalani masa pensiunnya maka pensiunan tersebut sudah mampu menyesuaikan diri dan menerima masa pensiunnya. ${ }^{13}$

\section{KESIMPULAN}

Prevalensi depresi pada pensiunan Pegawai Negeri Sipil yang mengambil dana pensiun di Bank BTPN Cabang M. Yamin Padang yaitu 27,8\%.

Prevalensi depresi pada pensiunan Pegawai Negeri Sipil yang mengambil dana pensiun di Bank BTPN Cabang M. Yamin Padang berdasarkan usia terbanyak berada pada kategori usia $\geq 60$ tahun.

Prevalensi depresi terbanyak pada laki-laki.

Prevalensi depresi berdasarkan golongan/pangkat didapatkan prevalensi terbanyak yaitu pada pensiunan PNS golongan IIla.

Prevalensi depresi berdasarkan lama pensiun terbanyak ditunjukkan pada pensiunan PNS yang menjalani lama pensiun $\leq 10$ tahun.

\section{UCAPAN TERIMA KASIH}

Ucapan terima kasih penulis sampaikan kepada pembimbing dr. Amel Yanis, Sp.KJ(K) dan Dra. Hj. Elmatris, Sy, M.S yang telah membimbing dan membantu penulis dalam menyelesaikan penelitian ini. Penulis juga mengucapkan terima kasih kepada pihak Bank BTPN Cabang M. Yamin Padang dan responden yang telah membantu penulis dalam rangka menyelesaikan penelitian ini.

\section{DAFTAR PUSTAKA}

1. Mulyono. Pensiun dini? Siapa Takut! : kehidupan baru dimulai setelah pensiun. Jakarta: PT. Elex Media Komputindo; 2011.

2. Rini JF. Pensiun dan pengaruhnya. 2001 (diunduh 10 September 2012). Tersedia dari: URL: HYPERLINK http://www.e-psikologi.com/artikel/ lanjut-usia/pensiun-dan-pengaruhnya.

3. Dinsi V, Setiati E, Yuliasari E. Ketika pensiun tiba. Jakarta: Wijayata Media Utama; 2006.

4. Badan kepegawaian Daerah. Pensiun. 2008 (diunduh 20 Januari 2013). Tersedia dari: URL: HYPERLINK http://bkd.kuningankab.go.id/pensiun 
5. Nevid JS, Rathus SA, Green B. Psikologi abnormal. Edisi ke-5, Jilid II. Alih bahasa: Tim Psikologi Universitas Indonesia. Jakarta: Erlangga; 2005.

6. Beck AT, Alford BA. Depression: causes and treatment. Philadephia: University of Pennsylvania Press; 2009.

7. World Health Organization (WHO). Depression. 2011. (diunduh 18 Januari 2013). Tersedia dari: URL: HYPERLINK http://www.WHO.int

8. Ide P. Strategic thinking to fight frustation. Jakarta: PT. Elex Media Komputindo. 2010.

9. Eliana R. Konsep diri pensiunan. 2003. (diunduh 14 November 2012). Tersedia dari: URL: HYPERLINK http://library.usu.ac.id/download/ fk/psikologi-rika\%20eliana.pdf
10. Ermayanti S. Hubungan antara persepsi terhadap dukungan sosial dengan penyesuaian diri pada masa pensiun (skripsi). Yogyakarta: Fakultas Psikologi Universitas Wangsa Manggala; 2006.

11. Mahmoudi G, Vahedi M, Hasani S. Studi of depression in nurses at the University of Medical Science Affiliated Hospitals in 2007. World Applied Sciences Journal 6. 2009;(9):1200-4.

12. Wiguna IM, editor (penyunting). Sinopsis psikiatri Jilid I. Tangerang: Binarupa Aksara Publisher. 2010.

13. Agustianto D. Hubungan stres dengan koping lansia pada masa pensiun di RW 11 komplek skripsi). Jakarta: Fakultas IImu Kesehatan Universitas Pembangunan Nasional "Veteran"; 2011. 